\title{
KUALITAS PELAYANAN PUSKESMAS TERHADAP PENGGUNA PROGRAM BPJS KESEHATAN DI PUSKESMAS PAGURAWAN
}

\author{
Mardiansyah \\ Fakultas IImu Sosial dan Ilmu Politik \\ Universitas Islam Sumatera Utara, Jl. SM. Raja, Medan \\ e-mail : Mardiansyah@fisip.uisu.ac.id \\ DOI : https://doi.org/10.35451/jkg.v1i2.115
}

\begin{abstract}
Health care for the poor is a complex and so important problem, so that all humans are entitled to proper health services. The Puskesmas is the leading party in health services, therefore the existence of the Puskesmas is very important. The purpose of this study was to determine the quality of service at Pagurawan Health Center to BPJS patients. This research was qualitative descriptive in nature at Pagurawan Health Center, Medang Deras District, Batubara Regency. Data collection techniques are carried out through interviews and documentation. Analysis of the data used in this study is descriptive data analysis. In this case the Pagurawan Health Center has shown good service by providing services that meet the expectations and satisfaction of BPJS patients, for example: the clarity of health financing is in very good category, the environmental security of the hospital is in good category, fairness in obtaining services is in sufficient categories, clarity about tasks and the functions of health workers is in good categories, and the availability and clarity of information is in very good categories.
\end{abstract}

Keywords: Health Services, BPJS Health, Poor Health

\section{PENDAhuluan}

Undang-Undang No. 36 Tahun 2009 tentang Kesehatan menegaskan bahwa setiap orang mempunyai hak yang sama dalam memperoleh akses atas sumber daya di bidang kesehatan dan memperoleh pelayanan kesehatan yang aman, bermutu dan terjangkau. Berdasarkan undang undang tersebut maka dapat disimpulkan bahwa kesehatan merupakan suatu yang esensi dan merupakan hak asasi manusia untuk memperoleh pelayanan kesehatan yang layak.

Berdasarkan delik hukum tersebut, telah banyak berkembang lembaga atau badan penyelenggara jaminan kesehatan masyarakat. Badan Penyelenggara Jaminan Sosial (BPJS) Kesehatan yang merupakan pengganti dari Jaminan Kesehatan Masyarakat
(Jamkesmas) yang merupakan lembaga yang menjamin adanya pelayanan kesehatan kepada seluruh warga negara Indonesia. BPJS mengatur beberapa hal terkait pelayanan kesehatan masyarakat seperti fasilitas kesehatan cakupan pelayanan, serta prosedur dan alur pelayanan yang dapat diakses masyarakat pengguna BPJS Kesehatan (BPJS, 2018).

BPJS sudah mengubah pola pelayanan kesehatan, yang selama ini hanya memberikan pelayanan kesehatan dasar berubah menjadi pelayanan kesehatan menyeluruh dengan mengikuti ketentuan dan prosedur yang ditetapkan pemerintah (Kiswanto, 2006).

Melalui pemanfaatan BPJS banyak penduduk miskin yang merasa terbantu 
dalam mengakses pelayanan

kesehatan. Kiswanto (2006)

menyatakan bahwa $80,42 \%$ responden yang menggunakan askes untuk mengakses pelayanan kesehatan. Namun demikian, dibeberapa daerah mendapatkan kendala dalam memberikan manfaat BPJS pada masyarakat miskin, seperti di Nusa Tenggara Timur terjadi kendala pelayanan kesehatan akibat minimnya dana yang disediakan pemerintah daerah dalam memenuhi kebutuhan pelayanan kesehatan (Lestari, 2009).

Menurut Siswanto, dkk (2015) ada beberapa dimensi yang menunjukkan kualitas pelayanan kesehatan pada masyarakat, yaitu responsiveness, assurance, emphaty, tangibles dan reability. Dimensi reability adalah mengenai kepastian biaya, kepastian pelaksanaan pelayanan, dan alur pelayanan. Dimensi responsiveness adalah terkait pelayanan dalam kegiatan preventif yaitu kegiatan rujukan terhadap Ibu melahirkan atau pasien yang kontrol. Dimensi assurance adalah terkait kualitas pelayanan kesehatan berupa rasa aman dan nyaman dalam memperoleh pelayanan kesehatan.

Dimensi emphaty adalah mengenai kesempatan untuk menyampaikan apa yang menjadi keluhan atas pelayanan tenaga kesehatan. Adapun dimensi tangibles adalah mengenai fasilitas fisik seperti ruangan pelayanan maupun persediaan obat-obatan. Diantara kelima dimensi tersebut hanya kualitas pelayan pada reability yang perlu mendapat perbaikan pelayanan.

Lebih sederhananya, aspek yang menjadi penunjang pelayanan kesehatan bagi masyarakat adalah: kejelasan pembiayaan kesehatan; keamanan lingkungan rumah sakit; keadilan dalam mendapatkan pelayanan; kejelasan tentang tugas dan fungsi petugas kesehatan; ketersediaan dan kejelasan informasi (Marina, 2008).

Oleh karena itu penelitian ini bertujuan untuk mengetahui kualitas pelayanan
BPJS Kesehatan guna meningkatkan kesehatan masyarakat miskin.

\section{METODE PENELITIAN}

Penelitian ini berlokasi di Puskesmas Pagurawan Kecamatan Medang Deras Kabupaten Batu Bara, yang berlokasi di Desa Pangkalan Dodek, Kecamatan Medang Deras, Kabupaten Batu Bara.

Jenis Penelitian ini menggunakan jenis penelitian diskriptif kualitatif yang berusaha mengungkapkan fakta atau realita sosial tertentu dengan mengembangkan konsep dan menghimpun data tetapi tidak melakukan pengkajian hipotesis (Singarimbun, 1989). Jadi penelitian ini berusaha menggambarkan bagaimana kualitas pelayanan pasien Jamkesmas pada Puskesmas Pagurawan Kecamatan Medang Deras Kabupaten Batu Bara.

Sumber data penelitian ini terdiri data hasil wawancara dengan Kepala Puskesmas Pagurawan, petugas administrasi Puskesmas, petugas bagian pendaftaran pasien Puskesmas Pagurawan, Kepala tim peningkatan mutu Puskesmas Pagurawan, pasien dan pengunjung Puskesmas Pagurawan yang berjumlah 40 orang serta observasi yang dilakukan di Puskesmas Pagurawan terkait pelayanan kesehatan masyarakat.

Data yang ada kemudian dianalisis menggunakan model interaktif dari Miles dan Huberman (Sutopo, 2006) dengan tiga komponen yaitu: reduksi data, sajian data dan penarikan kesimpulan dari sajian data yang tersusun. Ketiga komponen diatas akan berinterkasi dengan proses pengumpulan data sebagai proses siklus. Dalam penelitian ini, penulis tetap berada dalam lingkungan interakasi tersebut sampai pengumpulan data bergerak ke reduksi data, penyajian data dan pengambilan kesimpulan.

Adapun data pendukungnya adalah data kependudukan serta data kependudukan yang memanfaatkan pelayanan kesehatan di daerah 
kabupaten Batu Bara. Berikut ini adalah kriteria kualitas pelayanan kesehatan berdasarkan responden:

Tabel 1. Kriteria Kualitas Pelayanan Kesehatan

\begin{tabular}{lc}
\hline Kriteria & Persentase \\
\hline Sangat Baik & $\geq 80 \%$ \\
Baik & $60-79 \%$ \\
Cukup & $41-59 \%$ \\
Kurang & $\leq 40 \%$ \\
\hline
\end{tabular}

\section{HASIL PENELITIAN}

Berdasarkan hasil observasi, diperoleh data jumlah penduduk di Kabupaten Batu Bara ada berjumlah 404.988 penduduk. Dari Jumlah Penduduk tersebut hanya ada $23,77 \%$ yang medapat Program Indonesia Pintar, $17,57 \%$ medapat Program Keluarga Sejahtera, 15,19\% mendapat program keluarga harapan serta 27,28\% mendapat program BPJS yang dinyatakan dalam tabel berikut.

Tabel 2. Jumlah Penduduk yang Mendapatkan Program Pemerintah Untuk Rakyat Miskin

\begin{tabular}{|l|r|c|}
\hline $\begin{array}{l}\text { Jenis Program } \\
\text { Untuk Rakyat } \\
\text { Miskin }\end{array}$ & $\begin{array}{c}\text { Jumlah } \\
\text { Penduduk }\end{array}$ & Persen \\
\hline $\begin{array}{l}\text { Program } \\
\text { Indonesia Pintar }\end{array}$ & 96.266 & 23,77 \\
\hline $\begin{array}{l}\text { Program } \\
\text { Keluarga } \\
\text { Sejahtera }\end{array}$ & 71.156 & 17,57 \\
\hline $\begin{array}{l}\text { Program } \\
\text { Keluarga } \\
\text { Harapan }\end{array}$ & 61.518 & 15,19 \\
\hline Program BPJS & 110.269 & 27,28 \\
\hline $\begin{array}{l}\text { Total Penduduk } \\
\text { Kab. Batu Bara }\end{array}$ & 404.988 & 100 \\
\hline
\end{tabular}

(Sumber: BPS Kab. Batu Bara, 2018)

Berdasarkan Hasil Observasi terhadap jumlah pendudukan Desa Pangkalan Dodek, Kecamatan Medang Deras, Kabupaten Batu Bara, diperoleh ada sekitar 27,28\% dari 44.952 penduduk yang mengikuti asuransi kesehatan atau program BPJS. Adapun Penduduk yang memanfaatkan pelayanan kesehatan di kabupaten Batu Bara, dinyatakan dalam tabel berikut:

Tabel 3. Jumlah Penduduk yang Memanfaatkan Pelayanan Kesehatan

\begin{tabular}{|l|r|c|}
\hline $\begin{array}{l}\text { Pemanfaatan } \\
\text { Yankes }\end{array}$ & $\begin{array}{l}\text { Jumlah } \\
\text { Penduduk }\end{array}$ & Persen \\
\hline Memanfaatkan & 30.500 & 27,66 \\
\hline $\begin{array}{l}\text { Belum } \\
\text { Memanfaatkan }\end{array}$ & 79.769 & 72.34 \\
\hline Total & 110.269 & 100 \\
\hline
\end{tabular}

(sumber: BPS Kab. Batu Bara, 2018)

Berdasarkan wawancara yang diberikan kepada beberapa narasumber, diperoleh beberapa hal, yaitu:

Tabel 4. Kualitas Pelayanan Kesehatan oleh Responden

\begin{tabular}{|l|l|l|}
\hline \multicolumn{1}{|c|}{$\begin{array}{c}\text { Aspek Kualitas } \\
\text { Pelayanan }\end{array}$} & \multicolumn{2}{c|}{ Persentase } \\
\cline { 2 - 3 } & Baik & Kurang \\
\hline $\begin{array}{l}\text { kejelasan pembiayaan } \\
\text { kesehatan; }\end{array}$ & 87,5 & 12,5 \\
\hline $\begin{array}{l}\text { keamanan lingkungan } \\
\text { rumah sakit; }\end{array}$ & 77,5 & 22,5 \\
\hline $\begin{array}{l}\text { keadilan dalam } \\
\text { mendapatkan } \\
\text { pelayanan; }\end{array}$ & 57,5 & 43,5 \\
\hline $\begin{array}{l}\text { kejelasan tentang } \\
\text { tugas dan fungsi } \\
\text { petugas kesehatan; }\end{array}$ & 70,0 & 30,0 \\
\hline $\begin{array}{l}\text { ketersediaan dan } \\
\text { kejelasan informasi }\end{array}$ & 80,0 & 20,0 \\
\hline
\end{tabular}

Berdasarkan tabel 4 diketahui bahwa kejelasan pembiayaan kesehatan sudah sangat baik $(87,5 \%)$, keamanan lingkungan rumah sakit termasuk kategori baik $(77,5 \%)$, keadilan dalam mendapatkan pelayanan termasuk kategori cukup $(57,5 \%)$, kejelasan tentang tugas dan fungsi petugas kesehatan termasuk kategori baik $(70 \%)$, serta ketersediaan dan kejelasan informasi termasuk kategori sangat baik $(80 \%)$.

\section{Pembahasan}


Berdasarkan tabel 3 diperoleh kenyataan bahwa hanya ada $27,66 \%$ pengguna program BPJS Kesehatan yang memanfaatkannya untuk berobat di Puskesmas maupun Rumah Sakit di Kab. Batu Bara. Ini menunjukkan bahwa pengguna program BPJS di Kab. Batu Bara belum memanfaatkan fasilitas kesehatan yang ada secara maksimal.

Berdasarkan hasil wawancara terhadap masyarakat peserta BPJS terkait fasilitas dan kenyamanan tempat pelayanan di Puskesmas menyatakan bahwa fasilitas ruang tunggu yang disediakan Puskesmas seperti loket pendaftaran yang mudah dijangkau, kursi tunggu, tersedianya bahan bacaan, televisi, kamar mandi yang bersih, serta kebersihan lingkungan Puskesmas menambah kenyamanan bagi pasien selama menunggu antrian untuk diperiksa.

Berikut ini adalah beberapa kutipan dari wawancara yang dilakukan dengan masyarakat.

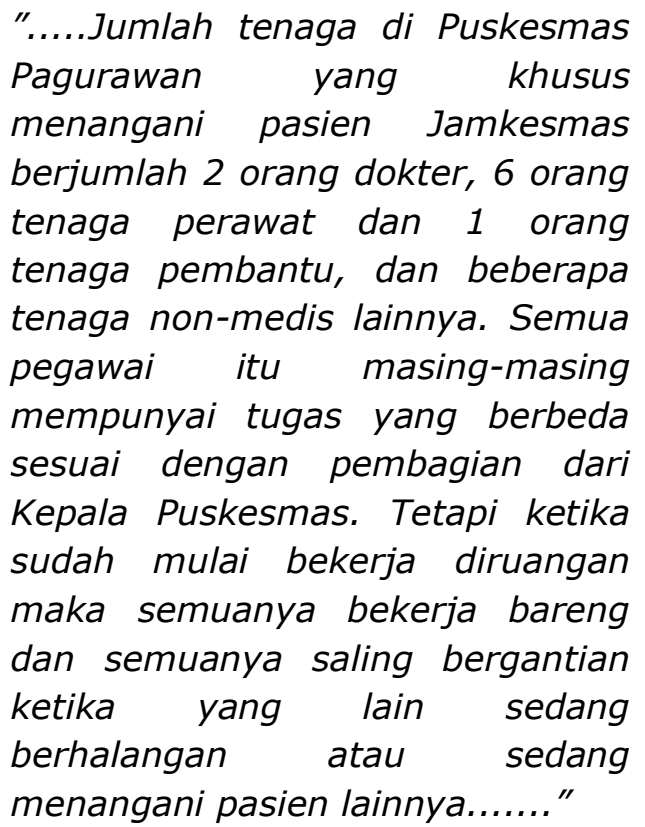

Pernyataan di atas menunjukkan adanya kejelasan tentang tugas dan fungsi petugas kesehatan yang ada di Puskesmas Pagurawan Kecamatan Medang Deras Kabupaten Batu Bara.
Terkait Kenyamanan dan keamanan lingkungan, berikut adalah pernyataan warga:

"....Menurut saya kenyamanan ditempat ini sudah memuaskan dan bisa membuat para pasien merasa betah saat menunggu, Saya bisa beristirahat dengan enak saat menunggu untuk diperiksa...."

Pernyataan warga lainnya mengatakan:

"....Disini itu kalo mau parkir enak mas, tempatnya ya lumayan luas, teduh dan aman. Karena ada petugas yang menjaga. Meskipun paarkirnya bayar 500 tapi gak apa-apa yang penting sepeda saya aman. Jadi saya kalo antri lama gak kuatir..."

Terkait Ketersediaan dan Kejelasan informasi dapat dilihat dari kutipan pernyataan warga berikut:

"....Kalau ada yang tidak saya ketahui, saya bisa langsung bertanya kepada petugas dan mereka juga tanggap apabila saya mengeluhkan sesuatu mngenai kesehatan anak saya..."

Pernyataan lainnya mengatakan:

"Saya dulunya tidak tahu sama sekali alur pelayanan disini apalagi untuk pasien jamkesmas seperti saya ini, karena saya baru pertama kali kesini, terus saya tanya kepada salah satu petugas akhirnya saya diberitahu sama petugasnya...."

Namun demikian, masih ada ketimpangan dalam pemberian pelayanan, terutama bagi pasien yang menggunakan kartu BPJS Kesehatan. Berikut adalah pernyataan salah seorang warga: 
"... ya kalo bisa cepat ditangani mas, kalo pasien jamkesmas seperti Ibu saya ini ya cepet ditangani dan prosedurnya tidak berbelit-belit. Jadi pasien itu tidak merasa dibeda-dibedakan mas. Kasihan pasien yang miskin atau pasien yang segera butuh penanganan tapi cuma pake kartu Jamkesmas. Kan kadang karena pasien itu cuma pake Jamkesmas, pelayanannya dipersulit bahkan ada yang ditolak..."

\section{KESIMPULAN}

Kesimpulan hasil dari penelitian ini adalah bahwa kualitas pelayanan badan BPJS Kesehatan di Puskesmas sudah baik, dimana:

1. kejelasan pembiayaan kesehatan sudah sangat baik $(87,5 \%)$,

2. keamanan lingkungan rumah sakit termasuk kategori baik $(77,5 \%)$,

3. keadilan dalam mendapatkan pelayanan termasuk kategori cukup $(57,5 \%)$,

4. kejelasan tentang tugas dan fungsi petugas kesehatan termasuk kategori baik $(70 \%)$, serta

5. ketersediaan dan kejelasan informasi termasuk kategori sangat baik $(80 \%)$.

\section{DAFTAR PUSTAKA}

BPS. 2018. Statistik Kesejahteraan Rakyat Kabupaten Batu Bara. Batu Bara: BPS Kab. Batu Bara.

Kiswanto, E. 2006. Jaminan Pemeliharaan Kesehatan bagi Masyarakat Miskin di Kota Yogyakarta. Populasi, Vol. 17 (1), p. 28-40.

Lestari, T.R.P. 2009. Implementasi Program Asuransi Kesehatan Masyarakat Miskin di Nusa Tenggara Timur. Jurnal Kesehatan Masyarakat Nasional, Vol. 3 (6), p. 264-269.

Marina, A. 2008. Analisis Kebijakan Ekonomi Publik Tentang
Pelayanan Kesehatan Masyarakat Miskin di Rumah Sakit Milik Pemerintah: Implementasi Program Jamkesmas di Jawa Timur. Balance Economics, Bussiness, Management and Accounting Journal, Vol. 5 (8).

Pemerintah R.I. 2018. Panduan Praktis Pelayanan Kesehatan. Jakarta: BPJS Kesehatan (diakses pada https://bpjskesehatan.go.id/bpjs/ )

Siswanto, H., Makmur, M., \& Lastiti, N. 2015. Analisis Kualitas Pelayanan Kesehatan dalam Operasionalisasi Program Mobil Sehat: Studi Pada Pusat Kesehatan Masyarakat Kedungpring Kabupaten Lamongan. Jurnal Administrasi Publik, Vol. 3 (11), p. 1821-1826. Sutopo. 2006. Metodologi Penelitian Kualitatif. Surakarta: UNS. 